\title{
WUJUD NILAI MORAL DALAM NOVEL AMIRA: CINTA DARI TANAH SURGA KARYA SULIWE
}

\author{
Zulfardi D \\ STKIP Yasika Majalengka \\ zulfardidarussalam@gmail.com
}

\begin{tabular}{ll}
\hline \multicolumn{2}{l}{ Article History } \\
\hline Received & : March 2020 \\
Accepted & : June 2020 \\
Published & : July 2020
\end{tabular}

Keywords

Manifestation of moral values

\begin{abstract}
This research is classified as a qualitative descriptive approach to literary sociology that aims to describe the manifestation of moral values in novel Amira: Cinta dari Tanah Surga. Data sourced from novel texts that were amalyzed using moral theory. The results of the study show that the from of moral values consists of three types, namely moral values in human relations with variants of have faith, pray to God, prayer and read the Quran. Moral values in relation to humans and themselves with variants of patience, sincerity, and responsibility. Moral value of human relations with other people with variants, of advice from fellow friends, parents love children, and the love of fellow friends
\end{abstract}

\begin{tabular}{l} 
Abstrak \\
\hline Penelitian ini tergolong deskriptif kualitatif dengan \\
pendekatan sosiologi sastra yang bertujuan untuk \\
mendeskripsikan wujud nilai moral dalam novel \\
Amira: Cinta dari Tanah Surga. Data bersumber dari \\
teks novel yang dianalisis dengan mengunakan teori \\
moral. Hasil penelitian menunjukkan bahwa wujud \\
nilai moral terdiri dari tiga jenis,yakni, nilai moral \\
dalam hubungan manusia dengan Tuhannya dengan \\
varian beriman, berdoa kepada Tuhan, shalat, dan \\
mengaji (membaca Alquran). Nilai moral dalam \\
hubungan manusia dengan diri sendiri memiliki varian \\
kesabaran, keikhlasan dan tanggung jawab. Nilai \\
moral hubungan manusia dengan manusia lain dengan \\
varian, nasihat antarteman, kasih sayang orang tua \\
kepada anak, dan kasih sayang antarteman
\end{tabular}

\section{A. Pendahuluan}

tetapi terlebih dahulu melalui hal-hal yang

Ajaran moral dalam karya sastra seringkali tidak secara langsung disampaikan, dengan tahap katarsis pada pembaca karya 
sastra. Meskipun sebelum mengalami katartis, pembaca dipersilahkan untuk menikmati dan menyaksikan peristiwa-peristiwa yang sebetulnya tidak dibenarkan secara moral, yaitu cerita yang menyebabkan pembaca senang tetapi juga muak. Jadi untuk menuju moral, seringkali ppembaca harus melalui proses menyaksikan adegan yang tidak sejalan dengan kepentingan moral.

Sejalan dengan uraian tersebut, diketahui bahwa semakin banyak fenomena yang terjadi sekarang di tengah masyarakat yang terkadang tidak mengindahkan perilaku menyimpang yang bertentangan dengan ajaran moral. Demikian juga hal nya dengan karya sastra. Contohnya, novel Novel Amira: Cinta dari Tanah Surga karya Suliwe". Novel ini mengisahkan tentang tokoh Amira seorang gadis periang dan cerewet yang memandang hidup berumah tangga adalah arena pertengkaran dan kesedihan. Selanjutnya dikisahkan Amira terlibat cinta segi tiga dengan Fatih dan Fahmi. Dalam novel ini disajikan konflik batin antar tokoh yang cukup banyak. Fokus cerita yang berpindah dari masa kini ke masa lalu membuat cerita ini memiliki alur yang membuat pembaca harus jeli memahami pesan moral yang ada di dalamnya. Pada bagian menjelang akhir cerita penulis dengan halusnya mengungkapkan rahasia yang terpendam dalam diri tokoh Fatih. Ending cerita sesuatu yang mengharukan ten tang hakikat dari sebuah cinta. Sehubungan dengan hal tersebut, pendalam penelitian ini akan dideskripsikan nilai moral dalam novel Amira: Cinta dari Tanah Surga karya Suliwe". Karya sastra yang diciptakan oleh pengarang mengandung nilai tertentu yang akan disampaikan kepada pembaca, misalnya nilai moral. Pembaca diharapkan dapat menemukan dan mengambil nilai tersebut. Salah satu karya sastra yang mengandung nilai moral adalah novel.

Novel merupakan cerita yang diemban oleh pelaku-pelaku tertentu dengan pemeranan, latar, serta tahapan dan rangkaian cerita tertentu yang bertolak dari hasil imajinasi pengarangnya sehingga menjadi suatu cerita (Aminuddin, 2009:66). Karya sastra tulis ini menarasikan tokoh-tokoh yang terlibat beserta konflik-konflik yang mereka miliki. Novel menyuguhkan tokohtokoh dan menampilkan serangkaian peristiwa secara tersusun. Namun jalan ceritanya dapat menjadi suatu pengalaman hidup yang nyata. Lebih dalam lagi novel mempunyai tugas mendidik pengalaman batin pembaca atau pengalaman manusia. Nurgiyantoro, (2010:3) mengatakan bahwa sebagai karya cerita fiksi, novel sarat akan pengalaman dan permasalahan kehidupan yang ditawarkan. Karena itu, novel harus tetap merupakan cerita menarik yang mempunyai bangunan struktur yang koheren dan tetap mempunyai tujuan estetik. Dapat disimpulkan bahwa novel merupakan salah satu bentuk karya sastra yang di dalamnya memuat nilai-nilai estetika dan nilai-nilai pengetahuan serta nilai-nilai kehidupan. Dengan demikian, 
sastra sebagai teks harus dilihat pula dalam konteks.

Menurrut pandangan sosiologi sastra budaya dan segala aspek yang ada di dalamnya merupakan titik tumpu bagi pengarang untuk dapat menggerakkan imajinasi. aspek budaya. Melalui budaya pengarang memasukan nilainilai moral sebagai pesan yang terkandung dalam karya sastra. Mempelajari budaya lewat sastra dan masyarakat, akan menemukan hakikat hidup manusia dan nilai-nilai yang melekat di dalamnya (Endraswara, 2011:186).

Berdasarkan pernyataan di atas, masalah penelitian ini difokuskan pada nilai moral. Nilai moral merupakan landasan sikap perilaku manusia dalam kehidupan sehari-hari. Menurut Bertens (2011:152) dalam arti tertentu nilai moral tidak merupakan suatu kategori nilai tersendiri di samping kategori-kategori nilai yang lain. Nilai tidak terpisah dari nilai-nilai jenis lainnya. Setiap nilai dapat memperoleh suatu "bobot moral", bila diikutsertakan dalam tingkal laku moral. Nilai moral tampak sebagai suatu nilai baru, bahkan sebagai nilai yang paling tinggi. Hal itu bisa lebih jelas dengan melihat ciri-ciri khusus nilai moral yaitu berkaitan dengan tanggung jawab, berkaitan dengan hati nurani, mewajibkan, serta bersifat formal. Nilai-nilai moral bersifat formal dalam mengikutsertakan nilai-nilai dalam suatu tingkah laku moral. Kajian aspek dasar moral adalah hati nurani, kebebasan dan tanggung jawab, hak dan kewajiban, serta nilai dan norma (Bertens, 2011:53-190).

\section{B. Metodologi}

Penelitian ini bertujuan untuk $\mathrm{m}$ mendeskripsikan wujud nilai moral tokoh utama dalam novel Amira: Cinta dari Tanah Surga karya Suliwe. Berdasarkan tujuan tersebut, maka metode yang digunakan dalam penelitian ini menggunakan penelitian deskriptif kualitatif dengan langkah sebagai berikut; (1) tahap penyediaan data dilakukan dalam bentuk pembacaan terhadap sumber data yang dilanjutkan dengan inventarisasi dan klasifikasi data berdasarkan focus penelitian. (2) Tahap analisis data dilajukan dengan cara menganalisis data yang telah diklasifikasikan berdasarkan teori moral dengan pendekatan sosiologi sastra, dan (3) Tahap penyajian hasil penelitian dalam bentuk menginterpretasikan hasil analisis data.

\section{Hasil Penelitian Dan Pembahasan Wujud Nilai Moral dalam Novel Amira : \\ Cinta Dari Tanah Surga}

Wujud nilai moral yang terdapat dalam novel Amira : Cinta dari Tanah Surga dapat dikatagorikan berdasarkan sifat dan kelakuan manusia yang melekat dalam menjalani hidup. Berbagai persoalan hidup dan penyelasaian yang muncul dapat memberikan sebuah gambaran tentang sesuatu yang diidealkan oleh pengarang. Wujud nilai moral dalam novel Amira : Cinta dari Tanah Surga yaitu wujud nilai moral dalam hubungan manusia dengan Tuhan, wujud nilai moral dalam hubungan manusia dengan manusia lain dan wujud nilai moral manusia dengan diri sendiri. Berikut akan dibahas menganai wujud 
nilai moral dalam novel Amira : Cinta dari Tanah Surga.

\section{a. Wujud Nilai Moral Dalam Hubungan Manusia Dengan Tuhan}

Hubungan antara Sang Pencipta dan yang diciptakan adalah suatu hubungan yang tidak mungkin dipisahkan. Manusia sebagai mahluq yang diciptakan Allah SWT, mustahil bisa berlepas diri dari keterikatannya denganNYA. Bagaimanapun tidak percayanya manusia dengan Allah, suka atau tidak suka, sadar atau tidak sadar manusia akan mengikuti sunatullah yang berlaku di alam semesta ini. Dalam novel Amira : Cinta dari Tanah Surga menemukan empat unsur hubungan manusia dengan Tuhan yaitu, beriman, berdoa pada Allah, shalat, dan mengaji.

\section{1) Beriman}

Pengertian iman menurut bahasa Arab yang artinya percaya. Sedangkan menurut istilah adalah membenarkan dengan hati, diucapkan dengan lisan dan diamalkan dengan tindakan (perbuatan). Beriman kepada Allah adalah membenarkam dengan hati bahwa Allah itu benar-benar ada dengan segala sifat keagungan dan kesempurnaanNya, kemudian pengakuan itu diikrarkan dengan lisan serta dengan amal perbuatan secara nyata. Beriman kepada Tuhan adalah kebutuhan yang sangat mendasar bagi seseorang. Data yang ditemukan dalam novel ini tentang beriman adalah sebagai berikut.

“Aku mencintaimu karena Allah....”
Kata-kata itu, kata yang spesial. Lambang cinta berbalut keikhlasan (NA/Brimn/10) "Tuhan sungguh indah kuasa-Mu..." NA/Brimn/21)

Kutipan data di atas merupakan nilai moral keimanan Fahmi pada kutipan nomor 10 dan Amira pada kutipan nomor 21 kepada Tuhan atas nikmat cinta dan nikmat karunia Tuhan kepadanya. Ia selalu mensyukuri atas seluruh nikmat Tuhan yang diberikan. Ia begitu mensyukuri atas nikmat yang diberikan Tuhan padanya karena ia yakin rasa syukur itu akan membawa keindahan dalam hidup dan cintanya. Hal demikian merupakan bentuk iman seseorang kepada Tuhannya.

Sebagai manusia biasa, sudah seharusnya kita mensyukuri anugerah yang diberikan. Dengan bersyukur, kita dapat lebih bijaksana dalam bersikap. Cara bersykur paling mudah sebenarnya adalah melihat pada kondisi diri sendiri. Bayangkan, banyak sekali orang yang merasa hidupnya serba kekurangan. Iri dan dengki melihat keberhasilan orang lain. Bahkan ada yang merasa Tuhan memberi hidup yang tidak adil karena nasib yang diterima menjadi lebih buruk dari yang lain. Namun, sedikit sekali dari mereka yang mencoba untuk menilai betapa setiap manusia adalah hasil karya cipta yang sempurna. Hal ini ditunjukan oleh Husna yang selalu bersyukur atas limpahan rahmat Tuhan untuk nya sehingga ia mampu menghafal juzamma dan mendapatkan hadiah jalan-jalan ke pantai. Kutipan novel tersebut sebagai berikut: 
Ya Allah, makacih banget ya, Husna sudah hapal juz amma. Makacih hadiah jalan-jalan ke pantainya. Allah baik, deh!!. (NA/Brimn/23)

Tuhan ingin Anda memiliki semangat rasa syukur dalam segala hal yang Anda lakukan serta katakan. Hiduplah dengan semangat berterima kasih dan Anda akan memiliki kebahagiaan serta kepuasan yang lebih besar dalam kehidupan. Rasa syukur akan memalingkan hati Anda kepada Tuhan dan membantu Anda mengenali pengaruh dan berkat-Nya dalam kehidupan Anda. Bahkan pada saat-saat paling sulit, Anda dapat menemukan banyak hal untuk disyukuri. Melakukan hal ini akan memperkuat dan memberkati Anda. Hal ini terdapat pada kutipan pada novel sebagai berikut:

Meniru kata-kata ayahnya dulu,
"jangan pernah mengeluh dengan
hidup, sesulit dan seberat apapun hidupmu. Selalulah tersenyum di depan siapapun walaupun kamu sedang menelan pil paling pahit di dunia! Kmoral kamu sedang banyak masalah, kmoral kamu merasa sendirian, maka ingatlah Allah karena ia selalu bersamamu. KUN FAYAKUN! Selalu ada harapan ditengah kesulitan. (NA/Brimn/30)

Pesan Fatih kepada Amira dengan meniru pesan ayahnya menandakan bahwa ini adalah pesan moral yang disampaikan dalam novel tentang bagaimana caranya kita bersukur dan percaya kepada Tuhan, kasih sayang Tuhan serta selalu percaya bahwa selalu ada harapan ditengah kesulitan karena kita tidak sendirian Allah bersama kita.

Terkadang pula moral buruk yang lain adalah sifat pesimis Amira dalam menghadapi cobaan hidup keluarganya. Ia selalu mengeluh, bahkan menyalahkan Tuhan akan nasib yang menimpa keluarganya. Gambaran sifat tersebut tampak pada kutipan di bawah ini.

“Ibu, kenapa kita selalu sedih?” bisik Amira pelan pada Bu Fatimah (NA/Brimn/47)

"Kapan keluarga kita akan merasakan kebahagiaan, Bu? Apakah kita akan selalu sedih? Akan dirundung banyak masalah? Entah mengapa aku merasa Tuhan tidak menyayangi kita Bu...rasanya Tuhan tidak adil... NA/Brimn/66)

Kutipan data di atas menggambarkan moral yang buruk, yakni pesimis. Pesimis adalah bersikap atau berpandangan tidak memiliki harapan baik (Taufik, 2009:46). Orang yang memiliki sifat pesimis selalu dalam keraguraguan dan merasa tidak yakin akan kemampuan diri sendiri. Jadi, orang yang memiliki sifat pesimis akan sulit untuk maju dan berkembang karena tidak berani menanggung risiko. Orang yang bersikap pesimis akan berfikir tentang kegagalan terlebih dahulu sebelum melakukan sesuatu. Ia merasa bahwa dirinya tidak mampu melakukan hal tersebut sehingga pekerjaan yang dilakukannya kurang maksimal. 
Nilai moral yang dapat diambil dari kutipan tersebut adalah bahwa terkadang hidup ini tidak selalu sempurna seperti yang kita harapkan. Terkadang hidup kita selalu dalam kesulitan dan penderitaan. Namun, kita tidak boleh mengeluh dan putus asa, apalagi sampai menyalahkan Tuhan. Karena sesungguhnya semua penderitaan yang kita alami merupakan sebuah ujian kehidupan dari Tuhan. Tidak ada ujian yang melampaui batas kemampuan kita. Hanya saja, seberapa kuat kita bersabar dan mendekatkan diri padaNya.

Selain moral buruk di atas, ada juga moral yang baik. Moral baik tersebut dimiliki oleh $\mathrm{Bu}$ Fatimah yang selalu sabar dan tawakal kepada Allah. Dalam khazanah perbendaharaan bahasa Indonesia kata yang setara maknanya dengan moral adalah moral, moral, nilai, dan karakter. Kata-kata ini sering disejajarkan dengan budi pekerti, tata susila, tata krama atau sopan santun (Faisal Ismail, 1998: 178). Hal tersebut tergambar pada kutipan berikut.

"Tidak, Sayang. Kita tidak akan sedih lagi. Suatu saat nanti kita akan merasakan kebahagiaan. Kita akan selalu tersenyum. Allah tidak akan pernah membiarkan hamba-Nya menderita. Allah itu maha penyayang. Allah juga berjanji dalam kitab-Nya bahwa sesudah kesulitan itu akan ada kemudahan. Suatu saat nanti, pertolongan Allah pasti datang. Yakinlah Sayang, pertolongan itu pasti datang!” (NA/Brimn/47)
Kutipan di atas dengan jelas menggambarkan moral yang baik, yakni sifat optimis. Optimis adalah sikap yang selalu berpengharapan baik dalam menghadapi segala hal (Taufik, 2009:33). Dengan adanya sifat optimis dalam diri kita, maka akan timbul semangat. Dengan adanya semangat Insya Allah akan menjadi orang yang berhasil.

Nilai moral yang dapat diambil dari kutipan-kutipan di atas adalah bahwa kita harus selalu sabar dan tawakal terhadap cobaan dan ujian yang menimpa kita. Jangan sampai kita berputus asa dan menjauh dari Allah. Karena Allah membenci orang-orang yang putus asa, dan akan menolong hambaNya yang mau bersabar dan tawakal kepadaNya. Tawakal artinya menyerahkan segala sesuatu kapada Allah setelah berusaha dengan sungguh-sungguh (Taufik, 2009:36). Apabiloa sudah berusah dengan sekuat tenaga, tetapi masih juga gagal kita harus bersabar. Bersabar tidak berarti pasrah atau berdiam diri, melainkan terus berusaha lebih giat dan berdoa.

\section{2) Berdoa pada Tuhan}

Kedekatan Allah pada orang yang berdo'a adalah kedekatan yang khusus -pada macam yang kedua- (bukan kedekatan yang sifatnya umum pada setiap orang). Allah begitu dekat pada orang yang berdo'a dan yang beribadah pada-Nya. Sebagaimana disebutkan dalam hadits pula bahwa tempat yang paling dekat antara seorang hamba dengan Allah adalah kmoral ia sujud. (Majmu’ Al Fatawa, 15/17) 
Siapa saja yang berdo'a pada Allah dengan menghadirkan hati kmoral berdo'a, menggunakan do'a yang ma'tsur (dituntunkan), menjauhi hal-hal yang dapat menghalangi terkabulnya do'a (seperti memakan makanan yang haram), maka niscaya Allah akan mengijabahi do'anya. Lebih khusus lagi jika ia melakukan sebab-sebab terkabulnya do'a dengan tunduk pada perintah dan larangan Allah dengan perkataan dan perbuatan, juga disertai dengan mengimaninya. (Tafsir Al Karimir Rahman, hal. 87)

Dengan mengetahui hal ini seharusnya seseorang tidak meninggalkan berdo'a pada Rabbnya yang tidak mungkin menyia-nyiakan do'a hamba-Nya. Pahamilah bahwa Allah benarbenar begitu dekat dengan orang yang berdo'a, artinya akan mudah mengabulkan do'a setiap hamba. Sehingga tidak pantas seorang hamba putus asa dari janji Allah yang Maha Mengabulkan setiap do'a. Hal tersebut tergambar sebagai berikut:

Allah kapan Engkau turunkan pertolongan-Mu? Kapan Engkau berikan satu kemudahan setelah engkau turunkan berjuta kesulitan? NA/Doa/64) Ya Allah tolonglah hamba-Mu ini... NA/Doa/64)

Amira dalam novel tersebut berserah diri kepada Allah dan berdoa sekaligus bertanya pada Tuhan kapan Tuhan memberikan kemudahan setelah kesulitan itu tiba. Amira hanya mengharapkan pertolongan pada Tuhan karena keyakinannya terhadap pertolongan Tuhan dengan berdoa.

\section{3) Shalat}

Shalat memiliki kedudukan yang sangat tinggi dalam Islam. Dia adalah tiang agama juga batas pemisah antara keislaman dengan kekufuran dan kemunafikan. Oleh karena itu, Rasulullah memberikan perhatian ekstra terhadap masalah shalat. Beliau Shallallahu 'alaihi wa sallam memberikan contoh pelaksanaannya secara detail, dari awal sampai akhir, dari takbir sampai salam.

Ini semua menunjukkan pentingnya shalat dalam Islam. Harusnya ini sudah cukup sebagai motivasi bagi kita, kaum Muslimin untuk selalu bersemangat dalam melaksanakan shalat. Terlebih jika kita memperhatikan berbagai keitimewaan shalat, maka tidak ada alasan lagi bagi kita untuk bermalas-malasan dalam melaksanakannya. Hal tersebut tergambar pada novel sebagai berikut:

Sepuluh menit. Mereka sudah siap shalat tahajud. Eyang Fahmi mengenakan baju kokoh putih, sarung kotak-kotak, dan peci hitam. Eyang Amira, Ummi Sarah, dan si kecil Husna pun sudah terbiasa menegakkan tahajud. Total ada sebelas rokaat mereka tahajud. Seuisai tahajud doapun bertaburan dari mereka (NA/Shlt/22)

Mata kecil Husna terbuka. Ia segera mengerti apa yang harus dilakukan. Memang ia sudah tebiasa shalat tahajud 
dan shalat subuh berjamaah. (NA/Shlt/23)

Pendidikan moral dalam keluarga begitu tercermin dalam novel ini. Dari kutipan tersebut tergambar jelas penanaman nilai moral untuk selalu menjalankan ibadah sholat tahajud setiap malam datang secara istiqomah, mendidik keluarga untuk terus menjaga istiqomah dalam beribadah shalat sunah maka akan menjadi suatu kebutuhan tersendiri pada setiap orang yang menegakkannya. Pelajaran yang baik untuk ditanamkan pada keluarga untuk terus menjaga istiqomah dalam beribadah.

Dalam keluarga Amira sudah menentukan jadwal secara istiqomah dari shalat fardhu 5 waktu berjamaah, shalat sunnah, dan mengaji. Kegiatan tersebut seperti sebuah kegemaran, kebiasaan dari keluarga Amira. Sehingga tidak ada keterpaksaan dalam beribadah.

\section{4) Mengaji}

Secara terminologi, al-Qur'an adalah firman Allah dan bukan makhluk-yang berarti ada awal dan akhir. Al-qur'an diturunkan dengan huruf serta maknanya. Al-Qur'an terpelihara hingga hari akhir dan membuktikan kebenaran ajaran Nabi Muhammad SAW. AlQur'an bersifat esensial baik dengan huruf maupun suara. Ke-esensial-an itu hanya diketahui oleh Allah sedangkan makhluk tidak mampu dan juga tidak perlu menelusurinya terlalu dalam. Firman Allah tidak lepas dariNya. Sesuatu yang tidak lepas dari Allah selamanya bukan makhluk. Umat Islam disarankan atau bahkan diwajibkan untuk tidak berdebat dengan pihak yang mengusung opini baru tentang Al-Qur'an atau pihak yang memilih abstain dalam artian apatis dan tidak perduli atas dialektika makhluk dan bukan makhluk atas AlQur'an. Ditilik dari segi definisinya tersebut, keutamaaan mengaji al-Qur'an tentu sangat banyak dan bermanfaat.

Secara historis, pada zaman Nabi Muhammad SAW, Al-Qur'an dihafalkan secara istiqomah dan kontinyu sebab hafalan para sahabat Nabi saat itu sangat kuat. Al-Qur'an ditulis pada pelepah kurma, batu cadas, belikat unta, dan lain sebagainya. Sewaktu itu, banyak dari Al-Qurra atau penghafal Al-Qur'an berjumlah tujuh puluh orang di hadang oleh suku Bani Sulaim dan di bunuh di dekat sumur Ma'unah. Darisini, para sahabat nabi utamanya Abu Bakar As-Shiddiq khawatir akan kontinyuitas keberadaan Al-Qur'an lalu meminta bantuan untuk mengumpulkan tulisan-tulisan alQuran tersebut agar tidak hilang. Pada masa Sahabat Usman Bin Affan, mushaf al-Qur'an dibukukan.

Berbakti kepada Allah adalah tugas utama manusia hidup di dunia. Salah satu caranya adalah dengan mengetahui, menghayati dan mengimani Al-Qur'an secara sungguh-sungguh sebab al-Qur'an adalah firman-Nya. Jika ingin dekat dengan Allah, maka pelajarilah Al-Qur'an dan As-sunnah. Allah memberikan garansi kepada makhluk yang mencintai, mengkaji dan menghayatinya dalam kehidupan sehari-hari. 
Hal tersebut tergambar pada kutipan novel sebagai berikut:

Ia Eyang...hari ini Husna sudah hafal juz tiga puluh. Tadi barusan di muraja'ah (cek hafalan) sama Ummi. (NA/Mgj/14)

Setelah shalat subuh berjamaah, mereka tadarus bersama. Hari ini bacaan Husna sampai pada juz dua. (NA/Mgj/14)

Pada kutipan novel nomor 013 dan 014 menggambarkan suatu pendidikan pada keluarga yang dilakukan secara istiqomah. Husna seorang anak kecil yang sudah didik sedari kecil untuk selalu istiqomah beribadah pada Tuhannya dari shalat wajib, sunah, dan selalu diajarkan untuk bertadarus Al-Quran. Pendidikan keluarga yang baik untuk dicontoh dan diterapkan siapapun. Gambaran keluarga yang selalu menjalankan istiqomah dalam beribadah tercermin dalam setiap alur cerita pada novel Amira: Cinta dari Tanah Surga.

Selesai dengan surah al-Fatihah, mereka melantunkan sebuah surah yang entah kenapa sangat disukai oleh Fatih. Sebuah surah yang dijadikan mahar oleh Fahmi untuk melamar Amira waktu itu. Sampai kini mereka pun tidak tahu mengpa Fatih sangat menyukai surah ini. Mungkin karena ada sebuah ayat yang sama dan diulang berkali-kali dalam surah itu. Fabiayyi aalaaa irabbikum tukadzdzibaan. (QS. Ar-Rahman)
"Maka nikmat dai TuhanMu yang manakah yang kamu dustakan?"( NA/Mgj/34)

Pada novel ini bukan hanya menceritakan keistiqomahan keluarga Amira dalam beribadah. Novel ini juga menceritakan seorang hamba yang sangat mencintai kitab suci Tuhannya yang menandakan tokoh dalam novel tersebut diceritakan tentang kecintaannya terhadap Tuhannya dan selalu bersukur dengan menandakan tokoh Fatih yang menyukai QSArrahman yang menandakan Fatih seorang tokoh yang selalu bersukur.

\section{b. Wujud Nilai Moral dalam Hubungan Manusia dengan Diri Sendiri}

Perilaku hubungan manusia dengan dirinya sendiri diklasifikasikan pada semua wujud nilai moral yang berhubungan dengan individu sebagai pribadi yang menunjukkan akan eksistensi individu tersebut dengan berbagai sikap yang melekat pada dirinya. Persoalan manusia dengan dirinya sendiri menurut Nurgiyantoro (2009: 324) dapat bermacam-macam jenisnya dan tingkat intensitasnya. Varian yang terdapat dalam novel Amira : Cinta dari Tanah Surga terdapat tiga unsur hubungan manusia dengan diri sendiri yaitu, Kesabaran, keikhlasan, dan tanggungjawab.

\section{1) Kesabaran}

Kesabaran merupakan salah satu ciri mendasar orang yang bertaqwa kepada Allah SWT. Kesabaran merupakan setengahnya keimanan. 
Suliwe, sebagai pengarang novel ini telah memberikan sentuhan moralitas yang sederhana namun langsung mengena. Sikap menerima apapun yang Tuhan berikan kepada kita terlihat dalam novel Amira: Cinta dari Tanah Surga yaitu pada tokoh $\mathrm{Bu}$ Fatiman. Bu Fatimah menerima cobaan dari Tuhan yaitu berupa penyakit kanker jaringan lunak yang bersarang pada tubuhnya. Cara $\mathrm{Bu}$ Fatimah menerima penyakit mematikan dengan kesabaran dan keihklasan akhirnya membuahkan hasil kesembuhan. Cara $\mathrm{Bu}$ Fatimah menghadapi dan menerima cobaan dari Tuhan dapat dijadikan contoh dalam kehidupan sehari-hari. Mengenai kesabaran yang ditunjukkan Bu Fatimah dapat dilihat pada kutipan berikut.

"Tenang bu...sabar...pasti kami akan melunasi semua utang kami," bu Fatimah tetap sabar menghadapi bu Rumi. Memang ia sudah terbiasa dengan keadaan seperti itu. (NA/Sbr/46) Kesabaran yang digambarkan pada watak tokoh bu Fatimah yang selalu menghadapi ujian dan cobaan dari Tuhan untuk nya dari mulai suami yang suka menampar dan meminum-minuman keras bahkan sampai menghadapi permasalahan hutan dengan bu Rumi yang selalu menagih dan berkata kasar kepadanya. Ketegaran dan kesabaran bu Fatimah dalam menghadapi setiap ujian menjadi contoh sifat moral yang harus dimiliki seseorang jika menghadapi setiap ujian dan musibah seharusnya kita menghadapinya dengan penuh kesabaran dan tawakal.

"Jangan bicara begitu, Amira! Allah itu Maha Penyayang. Pertolongan-Nya pasti akan datang. Cepat atau lambat. Saat itu kita akan bahagia. Allah akan menghilangkan segala kesedihan kita. Allah sangat menyayangi kita, Nak. Dia sangat menyayangi keluarga kita. SANGAT...( NA/Sbr/66).

Kutipan di atas dengan jelas menggambarkan moral yang baik, yakni sifat optimis. Optimis adalah sikap yang selalu berpengharapan baik dalam menghadapi segala hal (Taufik, 2009:33). Dengan adanya sifat optimis dalam diri kita, maka akan timbul semangat. Dengan adanya semangat Insya Allah akan menjadi orang yang berhasil.

Nilai moral yang dapat diambil dari kutipan-kutipan di atas adalah bahwa kita harus selalu sabar dan tawakal terhadap cobaan dan ujian yang menimpa kita. Jangan sampai kita berputus asa dan menjauh dari Allah. Karena Allah membenci orang-orang yang putus asa, dan akan menolong hambaNya yang mau bersabar dan tawakal kepadaNya. Tawakal artinya menyerahkan segala sesuatu kapada Allah setelah berusaha dengan sungguh-sungguh (Taufik, 2009:36). Apabiloa sudah berusah dengan sekuat tenaga, tetapi masih juga gagal kita harus bersabar. Bersabar tidak berarti pasrah atau berdiam diri, melainkan terus berusaha lebih giat dan berdoa. 


\section{2) Keikhlasan}

Keikhlasan adalah menerima apapun yang telah diberikan kepada kita dengan sungguh-sungguh tanpa mengharapkan imbalan. Dalam hal ini yang dimaksud keikhlasan adalah menerima takdir yang telah Tuhan berikan. Sebuah iman dalam tubuh seorang manusia akan berimbas pada sikapnya untuk selalu menerima apapun takdir Tuhan dengan ikhlas. Novel ini akan menjadi contoh bagi pembaca mengenai ketabahan dan keihklasan tokoh Bu Fatimah dalam menghadapi takdir dari Tuhan. Nilai moral keikhlasan dapat dilihat pada kutipan berikut.

"Sudahlah nak...ikhlaskan bapakmu. Bapakmu sudah pergi. Ia sudah tenang." Kata bu Fatimah sambil memeluk putrinya dalam tangis dan kesedihan mendalam. (NA/Ikhls/63)

$$
\text { Lagi-lagi novel tersebut }
$$
menggambarkan keikhlasan dan ketabahan hati tokoh bu Fatimah yang kembali mengajarkan kepada kita tentang sifat moral yang bisa dijadikan sebagai contoh tauladan yang baik bagi kehidupan keluarga. Bu Fatimah yang sebenarnya sedih namun ia menutup kesedihannya di mata anaknya dan berusaha untuk menenangkan anaknya dan menasehati anaknya untuk mengikhlaskan kepergian bapaknya.

\section{3) Tanggung Jawab}

Tanggung jawab adalah kesadaran diri manusia terhadap tingkah laku dan perbuatan yang disengaja ataupun tidak disengaja. Tanggung jawab juga harus berasala dari dalam hati dan kemauan diri sendiri atas kewajiban yang harus di tanggung jawabkan. Timbulnya tanggung jawab itu karena seseorang bermasyarakat dengan yang lainnya dan hidup bersama dilingkungan alam. Manusia tidak boleh dan tidak bisa berbuat semuanya terhadap sesama manusia atau alam sekitarnya. Manusia harus menciptakan keseimbangan, keselarasan sesama manusia di lingkungan sekitar. Tanggung jawab bersifat kodrati yaitu tanggung jawab harus ada di dalam diri setiap manusia.

"Iya ibu ingat. Itu foto waktu kau masin enam tahun, sama seperti Sarah sekarang. Waktu itu kau sempat hilang di taman rekreasi itu. Ibu dan Ayah kebingungan mencarimu. Terutama ayahmu. Ia benar-benar ketakutan kalau kamu hilang dan tidak kembali. Ia berlari ke sana ke mari dan bertanya pada banyak orang. Hampir satu jam kami mencarimu. Setelah ditemukan, ternyata kamu lagi enakenakan makan es krim sama penjualnya." (NA/Tgjwb/66)

Kutipan tersebut menggambarkan tanggungjawab seorang ayah terus berusaha mencari Amira kecil yang hilang. Ayah tanpa lelah lari ke sana ke mari untuk mencari Amira. Ayah merasa hawatir dan menunjukan sesosok 
kepala rumah tangga yang bertanggungjawab terhadap keluarganya dan terus mencari Amira. Hal ini, mencerminkan nilai moral dari sosok ayah yang bertanggungjawab terhadap keluarganya.

\section{c. Wujud Nilai Moral dalam Hubungan Manusia dengan Manusia Lain}

Hubungan manusia dengan manusia lain dalam kehidupan bermasyarakat, seringkali terjadi gesekan kepentingan. Persoalan hidup sesama manusia dengan lingkungannya bisa berupa persoalan yang positif maupun persoalan yang negatif. Mengingat bahwa manusia pada dasarnya adalah makhluk sosial yang saling membutuhkan satu sama lain termasuk hubungan dengan alam sekitar sebagai kelengkapan dalam hidupnya terkadang menimbulkan berbagai macam permasalahan. Wujud nilai moral dalam hubungan manusia dengan manusia lain terdapat enam varian yaitu nasihat orang tua kepada anak, nasihat antar teman, kasih sayang orang tua kepada anak, kasih sayang anak kepada orang tua, kasih sayang antar teman, tanggung jawab orang tua kepada anak.

\section{1) Nasehat antar teman}

Nasihat merupakan suatu didikan dan peringatan yang diberi berdasarkan kebenaran dengan maksud untuk menegur dan membangun seseorang dengan tujuan yang baik. Nasihat selalu bersifat mendidik.

"Tabahkan hatimu Ra! Semua akan kembali seperti biasa. Ini sudah menjadi ketetapan Allah bahwa semua yang bernyawa pasti akan merasakan kematian." Kata Ardian sebagai ungkapan belasungkawa.( NA/Nsht $\operatorname{Tm} / 63$ )

“Isbhir, Ra! Allah Mahatahu apa yang terbaik bagi hamba-Nya. Dia selalu bersama orang-orang yang sabar." Kata Nuri.( NA/Nsh Tm/64)

Dalam kutipan di atas ditemukan bahwa kesetiawakawanan seorang sahabat yang merasakan kesedihan sahabatnya dan saling memberikan nasehat yang baik untuk sahabat yang terkena musibah. Hal ini, bisa menjadi pendidikan moral bagi para remaja untuk terus menjaga silaturahmi antar sahabat dan saling menasehati, mensuport sahabatnya dikala terkena musibah. Novel ini mengajarkan kepada kita pentingnya seorang sahabat.

\section{2) Kasih Sayang Orang Tua Kepada Anak}

Kasih sayang adalah suatu sikap saling menghormati dan mengasihi semua ciptaan Tuhan baik makhluk hidup maupun benda mati seperti menyayangi diri sendiri berdasarkan hati nurani yang dalam. kasih sayang merupakan pemberian rasa cinta yang diberikan oleh seseorang ke orang lainnya, atau kepada seluruh keluarganya, kasih sayang juga tercipta karena adanya rasa perhatian, penyayang, sehingga terciptalah rasa kasih sayang. Tidak hanya pasangan lawan jenis saja rasa kasih sayang yang tercipta tetapi kepada sahabat, keluarga dan teman-teman. Kasih sayang juga dapat mempersatukan orang yang sedang berselisih, banyak sekali sisi positif dari kasih sayang. 
Kasih sayang adalah faktor yang cukup penting untuk kehidupan anak, kasih sayang tidak akan dirasakan oleh si anak apabila dalam kehidupannya mengalami hal-hal misal kehilangan pemeliharaan orang tuanya, anak merasa tidak diperhatikan, dan kurang disayangi. Kasih sayang orang tua kepada anak dapat dilihat pada kutipan:

Ibu dan anak itu berpelukan. Mereka menangis. Sarah yang sedari tadi melihat pertengkaran itu dari kamarnya berjalan menghampiri Amira dan ibunya dan berbaur dalam pelukan itu. Ikut menangis.( NA/Syg Org/46)

Kutipan di atas menggambarkan pengorbanan seorang ibu sekaligus isteri kepada anak dan suaminya. Ia rela menerima dan merawat seorang anak hasil selingkuh suaminya. Bahkan, walau ayah dan ibu kandung anak itu sendiri tidak mau mengurusnya. Ia melindungi anak itu seperti anak kandungnya sendiri. Betapa besar pengorbanan ibu itu. Semua dilakukannya dengan penuh cinta.

Pada kutipan tersebut menggambarkan kisah kasih sayang dari keluarga $\mathrm{Bu}$ fatimah yang selalu mencurahkan kasih sayang kepada anak-anaknya Amira dan Sarah. Walau dalam hatinya sedih bercampur tangis namun beliau tetap menampakan ketegaran hatinya demi anakanaknya agar tidak merasa sedih. Kasih sayang orang tua terhadap anaknya selalu dicerminkan dalam novel ini dengan sosok bu Fatimah yang selalu melindungi, menjaga, dan mendidik anakanaknya agar menjadi anak yang solehah.

\section{3) Kasih Sayang Antar Teman}

Kasih sayang adalah suatu sikap saling menghormati dan mengasihi semua ciptaan Tuhan baik makhluk hidup maupun benda mati seperti menyayangi diri sendiri berdasarkan hati nurani yang dalam. kasih sayang merupakan pemberian rasa cinta yang diberikan oleh seseorang ke orang lainnya, atau kepada seluruh keluarganya, kasih sayang juga tercipta karena adanya rasa perhatian, penyayang, sehingga terciptalah rasa kasih sayang. Tidak hanya pasangan lawan jenis saja rasa kasih sayang yang tercipta tetapi kepada sahabat, keluarga dan teman-teman. Kasih sayang juga dapat mempersatukan orang yang sedang berselisih, banyak sekali sisi positif dari kasih sayang.

Oya, tadi Sarah sudah kuobati, kakinya sudah kuperban. Insya Allah sudah baikan. Sarah kusuruh untuk istirahat. Dia sedang tidur di kamarnya sekarang," tambahn nuri (NA/Syg Tm/64)

"Ia, terimakasih ya Nur atas bantuannya” (NA/Syg Tm/64)

"Ia sama-sama sudah. Sudah sepatutnya sesama saudara saling menolong”.( NA/Syg TM/64)

Novel Amira lagi-lagi memberikan gambaran kasih sayang kesetiakawanan seorang sahabat bernama Nuri kepada Amira dan keluarga. Ia selalu ada untuk membantu dan memberikan kasih sayangnya kepada Amira, 
Sarah, dan Bu Fatimah. Ia merasa mereka adalah saudara yang harus ditolong dan diberikan motivasi. Hal ini, menggambarkan nilai moral yang baik yang ditunjukan pada sosok Nuri yang selalu siap dan ikhlas untuk menolong sahabatnya Amira.

Selain kutipan tersebut, ada kutipan lain yang mencerminkan cinta dan pengorbanan. Hal tersebut tergambar pada kutipan berikut ini.

Mata Fatih berkaca-kaca. Menggigit bibirnya. Melawan isak yang terus meronta. Tetapi tak bisa.

Mengapa harus Fatih yang jadi saksi. Jabatan pemberi restu pernikahan perempuan yang dicintainya dalam diam. Andaikan mau sedikit ekstrim, ingin rasanya ia menjawab TIDAK saat Pak Naib bertanya, Bagaimana Saksi? Sah? Ah, tak mungkin tindakan tolol itu dilakukannya (NA/Syg TM/213)..

Kutipan di atas menggambarkan betapa cinta dan pengorbanan Fatih sangat besar terhadap sahabatnya dan perempuan yang dicintainya. Karena penyakit akutnya ia menyimpan sendiri perasaannya, berpura-pura tak memilki cinta itu. Bahkan ia rela menjodohkan pujaan hatinya dengan sahabatnya sendiri sebelum ia pergi untuk selamanya.

Gambaran cinta dan pengorbanan juga nampak pada kutipan berikut ini:

Malam itu, bercampur gelegar halilintar, tangis Fahmi memecah malam di pantai.
Punggung dan pantatnya dipukul berkalikali dengan bilah rotan. Siapa yang melanggar peraturan, ia pantas dihukum! Itulah peraturan yang dibuat oleh penjaga pantai. Setelah cukup dihukum, Fahmi dibawa keluar. Kali ini lebih berat, ia diikat di sebuah tiang di tengah halaman. Terguyur hujan. Tertusuk dingin. Tenggelam dalam tangis. Meraung kesakitan.

Fatih tak tega melihatnya. Ia mendekat ke tiang. Mengikatkan dirinya sendiri pada tiang. Mereka berdua terikat dalam sebuah ikatan yang kuat. Untuk selamanya (NA/Syg TM/174)."

Kutipan di atas nampak pengorbanan Fahmi kecil yang rela dihukum oleh penjaga panti daripada melihat sahabat kecilnya, Fatih, kedinginan dan kelaparan di luar. Ia tak menghiraukan larangan membantu Fatih meski hukuman yang akan diterimanya jauh lebih menyakitkan. Begitu pula dengan Fatih, ia menemani Fahmi menjalani hukumannya dengan mengikatkan sendiri dirinya di tiang. Betapa cermin dua anak manusia yang rela berkorban satu sama lain. Semuanya dilakukan karena rasa persaudaraan yang kuat.

\section{Simpulan dan Saran}

Berdasarkan hasil analisis data yang telah dilakukan terhadap sumber data dapat disimpulkan bahwa dalam novel Amira: Cinta dari Tanah Surga karya Suliwe ditemukan Wujud nilai moral sebagai berikut;1. Wujud 
nilai moral dalam hubungan manusia dengan Tuhan terdiri dari; beriman kepada Tuhan, Shalat, mengaji, 2. Wujud nilai moral hubungan manusia dengan dirinya sendiri terdiri dari; kesabaran, keikhlasan, dan tanggung jawab. 3. Wujud nilai moral hubungan manusia dengan manusia lain terdiri dari nasihat antar teman, kasih sayang orang tua kepada anak, dan kasih sayang sesama teman.

\section{DAFTAR PUSTAKA}

Aminuddin. (2009). Pengantar Apresiasi KaryaSastra. Bandung: Sinar Baru Algesindo.

Bertens. (2007). Etika. Jakarta: PT Gramedia Pustaka Utama.
Damono, Sapardi Joko. (1984). Sosiologi Sastra Sebuah Pengantar Ringkas. Jakarta: Pusat Pembinaan dan Pengembangan Bahasa.

Endraswara, Suwardi. (2006). Metodologi Penelitian Kebudayaan. Yogyakarta: Gadjah Mada University Press.

Endraswara, Suwardi (2008). Metodologi Penelitian Sastra: Epiatemologi, Model,Teori, dan Aplikasi. Yogyakarta: Medpress.

Endraswara, Suwardi (2011). Metodologi Penelitian Sosiologi Sastra. Yogyakarta: Buku Seru.

Nurgiyantoro, Burhan. (2009). Teori Pengkajian Fiksi. Yogyakarta: Gadjah Mada University Press.

Nurgiyantoro, Burhan. (2010). Teori Pengkajian Fiksi. Yogyakarta: Gadjah Mada University Press.

Taufik, Mokhamad. (2009). Akidah Akhlak. Semarang: Aneka Ilmu. 